Vol.6I.] GEOLOG OF PART OF THE CONGO FREE STATE.

30. Notes on the Geological Aspect of some of the North-Eastern Territories of the Congo Free State. By Gaston Fícix Joseph Preumont (communicated by J. A. Howe, B.Sc., F.G.S.); with Petrological Notes by John Allen Howe, B.Sc., F.G.S. (Read April 19th, 1905.)

\title{
[Plates Xlif-Xliv.]
}

\section{Introduction.}

Is $1902 \mathrm{I}$ had the honour of being commissioned by the Government of the Congo Free State, as mining-engineer and geologist, to accompany an exploratory mission sent to their north-eastern territories, and I had the opportunity of taking a few notes on the geological aspect of that part of Africa, which is as yet little known to the geologist.

It has occurred to me that the observations recorded during nearly two years spent in that region, although no doubt rery incomplete, might possibly be found of some interest.

The Government of the Congo Free State have given me in Africa in a very generous way, through all their officials, every assistance to carry out the investigation of that large tract of country : and I beg to be allowed here to mention my debt of gratitude towards them, as also to thank the Secretary-General of the Interior, Commandant Liebrecht, for the kind permission which he has granted me to bring these notes before this Society.

I am also greatly indebted to Mr. J. Allen Howe, who has kindly undertaken the petrological description of the rocks, for his vaiuable assistance and advice.

The Uelle district and the Lado Enclave are the north-easternmost provinces of the Congo Free State. They cover an area at least six times as large as Belgium, and the Velle district alone extends over 72,000 square miles. On the map it presents the shape of a long and broad belt of country nearly parallel to the Equator, stretching approximately from lat. $2^{\circ} 30^{\prime}$ to $5^{\circ}$ north, and from long. $23^{\circ} 30^{\prime}$ to $32^{\circ}$ east of Greenwich. Eastward it reaches as far as the Nile, and adjoins there the Uganda Protectorate. Northward it is bounded by the Egyptian province of Bahr-elGhazal, and farther west is divided from the French Congo by the River Mbomu, which by joining the Uelle River forms the Ubangi. On the south-west and south it is contiguous to other provinces of the Free State. The south-eastern extremity of the country so described reaches to Lake Albert.

From Boma, the capital of the State, on the Lower Congo, access is gained to the Uelle district by the usual route to the interior, namely, from Boma to Matadi by steamboat on the Lower Congo;

Q.J.G.S. No. 243. 
[Aug. 1905,

from Matadi, a line of railway, 260 miles long, crosses the mountainous belt of the Sierra de Cristal, and reaches the Upper Congo, which becomes once more narigable at Stanley Pool. From there large steamers ply regularly on the river, and cover in about 18 days the distance between Léopoldville and Bumba. Thence two or three days more enable the traveller to reach Ibembo, port of entry of the Uelle, situated on the River Itembiri, a direct tributary of the Congo.

The means of communication in the Uelle district are somewhat more primitive, and consist generally, either in using native canoes for travelling over the rivers (frequently full of rapids), or else in tramping overland along the native paths. Roads for wheeled traffic do not yet exist, although the Gorernment is now laying some out.

As in most parts of Africa, the work of exploring and of collecting obserrations in the Uelle is rendered somewhat tedious, if not actually difficult, by the nature of the country and its local conditions. In the Equatorial Forest one feels almost as if buried underground; the field of observation is reduced to the narrow strip of the natire footpath, and one goes often a day's march before meeting with any rocks in situ. In the vast plains of the north the same difficulties are found again, caused here by long grass, through which it is often necessary to cut a road. Only for three months in the year, after the grass has been burnt, can this obstacle be considered as slight.

The climate, thongh far from being as bad as it is represented, is nevertheless not one which conduces to the exertion of a maximum of energy in the field.

\section{Itinerary.}

I will now try to gire a brief idea of the ground covered in our itinerary.

The object of the first part of our journey was to reach Ndoruma, the northernmost station of the State in the Uelle district. Proceeding by the River Itembiri, from Ibembo, to Buta, we crossed here, overland towards the north, and reached the Uelle at Bima. From Bima we then followed the Rirer Uelle quite closely, and for the most part, by land-route, up to Niangara. Thence we proceeded across country in a northerly direction to Ndoruma. From this locality, which was for some time our base, we had the opportunity of seeing the country directly north of it, and of inspecting also the district east of it, as far as the hills of Mount Bundukwa.

The second portion of the journey comprised a visit to the country situated between Dungu and the neighbourhood of Mount Gaima; thence towards Farach and the Lado Enclave, through the central part of the Nile Territory, as far as the Nile itself. Finally, returning from the Nile Territory, we traversed the mountainous portion of the Uelle district, situated near Arebi, and later took a route more to the south, in order to visit Mount Tena. We returned to Buta by Poko, Zobia, and the Lipodongu Falls on the Rubi. 
Vol. 6i.] NORTH-EASTERN TERRITORIES OF THE CONGo FREE STATE. 643

\section{Physical Features.}

A large extent of the Uelle district is rery densely wooded, being part of the great Equatorial Forest, which stretches as far as the Bomokandi and Uelle rivers. North of these, the country consists generally of vast plains corered with grass and scrub, interrening between broad valleys, into which the forest sends out prolongations from its main area: the forest-growth naturally following the watercourses. The country reaches its greatest elevation towards the east, at the Nile-Congo watershed, where it attains an elevation of 3300 feet, and, in places, as much as 4000 feet; on the south-east, a wide area is hilly and even mountainous. In the north-eastern part, close to the Bahr-el-Ghazal, appears a group of hills of some importance, with Mount Bundukwa, Mount Yambili, and several smaller elevations.

Westward, the country becomes gradually lower and forms a series of broad undulations which produce hardly any visible effect on the contour. Through this monotonous country pierce, in places, groups of isolated hills, such as Mount Angba, on the Uelle, near Amadi; Mount Madjema, near Poko; Mount Tena, on the Bomokandi; and others of minor importance.

Close to Libokwa, a ridge of granite running north-west and south-east stretches quite close to the southern bank of the Velle, and extends towards the Falls of Lipodongu on the Rubi.

The Uelle district is extremely-well watered. The Uelle River arises from the mountains situated near Lake Albert, and traverses the district from east to west, throwing its network of tributaries northward and southward, orer a wide area representing more than 60,000 square miles. The southern tributaries are the most important; a fact easily accounted for, since the southern zone is more densely wooded, and has a rainfall heavier than that prevalent in the northern zone.

A rough parallelism is noticeable in the disposition of the principal affluents of the Uelle : north of the river the tributaries all run nearly north-east and south-west, while those on the south side trend more west-north-westward and east-south-eastward.

Owing to the small fall of the rivers and streams the country, in the rainy seasons, becomes extremely swampy : small rivers, of no importance at other times, often expanding over enormous floodgrounds. This is especially noticeable in the northern zone, where the country is more level and the ground more argillaceous. The Uelle, in common with most of its tributaries, generally winds its way through high banks of clayey alluvium, and runs through a broad basin, much too shallow to be termed a 'valley.' The course of the stream is interrupted by numerous rapids, which divide it into reaches of quieter water, easily navigable for native canoes. In flood-times the Uelle rises from 12 to 15 feet, and its volume of water is increased at least fivefold.

That the pitch of the river is not great is instanced between Suronga and Niangara, the difference of level being $42 \cdot 6$ feet for a distance of a little over 62 miles, with only two insignificant rapids. 


\section{Grologr.}

\section{Ibembo-Buta. Lipodongu. Itembiri-Rubi Basin.}

On leaving Ibembo, to proceed up the Itembiri River, towards Buta, the first rocks encountered are at the rapid of $G \hat{o}$, where the river changes its name into $\mathrm{Rubi}$.

The Buta Shales.-Beyond the junction of the Likati River with the Rubi, appears a formation of laminated shales borizontally stratified, and cropping ont on the river-banks. They are in appearance quite unmetamorphosed, and in places seem to pass into sandstone. They continue to be seen along the banks of the Rubi, right up to Buta.

Close to Buta, and apparently intercalated in the Buta Shales, is a small outcrop of oolitic limestone in irregular masses, many cubic yards in size, which are buried in a light-coloured clay-soil, forming here the southern bank of the Rubi. The forest, hereabouts $\mathrm{ra}$ ciense, prevents one from making a detailed investigation, and no information could be gathered as to the relative position of this outcrop with regard to the neighbouring shales. It looks like a local occurrence of no great extent. All along the Rubi River the Buta Shales are most regular in appearance, and quite horizonta? in position. They do not seem to extend to any considerable distance northward or eastward, as, in following up the course of the River Rubi (a road which we trarelled on the return-journey) they are only traced for about 20 miles farther east, a little before reaching the Falls of Lipodongu on the Rubi, where granite appears.

Northward we followed the Buta shales up to the Bali River, about 12 miles north, where we noticed an outcrop of soft grey sandstone, apparently running north-westward and south-eastward.

Granite.-Between the Bali and Iibokwa, and about 30 miles north of Buta, a rell-defined massire ridge of granite appears, running in a north-westerly and south-easterly direction; and the intervening country is made up of alluvium and clay in the depressions, while upon the slight eminences a limonitic puddingstone is often met with. From Libokwa to Bima on the Uelle, the same granite and ferruginous rocks are also abundant.

The altitude of the Rubi basin at Buta is about 1600 feet abore sea-lerel, and that of the Celle at Bima is about 2000 feet. Since the distance between the two places does not exceed 55 miles in a bee-line, the ascent is remarkable, and makes the basin of the Uelle much higher than that of the Rubi. The separation of the two basins is well-defined by this ridge of granite running westward close to the Uelle. South-eastward this granite-ridge appears to extend in the direction of the Lipodongu Falls on the Rubi.

In entering the Celle Basin, therefore, the main fact to be noticed is its granitic substratum. 
Vol.6I.] NORTH-EASTERN TERRITORIES OF THE CONGO FREE STATE. 645

$$
\text { Djabbir-Likati. }
$$

From Bima to Djabbir the Uelle takes a more north-westerly direction, and its course is interrupted by an immense number of rapids. We had no opportunity of visiting that part, but from the information gathered it would seem that granite is the prevalent rock.

A remarkable feature of that stretch of country is the peculiar direction, as well as the proximity of the course of the Likati River in its upper part, to that of the Uelle itself, there being an interval of not more than 15 miles between the two rivers.

Commandant Roget is said to have found a stanniferous diabase on the banks of the Uelle and in the neighbourhood of Djabbir. We have been unable to rerify this, and in the portion visited by us we never saw any stanniferous rocks.

\section{Bima-Bomokandi. Poko-Zobia.}

The distance between Bima and Bomokandi is given as 81 miles (teste Lemaire) by the waterway, the difference of level between the two places being about 82 feet.

As we travelled this route by canoes at the highest flood-time, little information could be gathered, except to show that the country was entirely granitic in its vature. At the numerous and strong rapids encountered, blocks and masses of granite were much in evidence, and near Bomokandi we noticed that the granite formed a ridge running north-west and south-east.

On the road followed overland from Poko to Zobia, and thence to the Rubi on our return-journey, we obtained a new traverse of the same country, but farther south. Here again granite was the prevalent rock, being principally found in the depressions and beds of streams, and mostly in isolated blocks buried in clay. In places, the lower portions of the grey argillaceous deposit, as the underlying granite was approached, became more and more like kaolin, and we observed that it was often used as whitervash for houses.

Above the kaolinized surface-deposit, which we take to represent the decumposed granitic substratum, we noticed a formation overlying it and distinct from it, which appears to be widely distributed throughout the Uelle district: a limonitic puddingstone, to which I shall refer again (p. 649).

From Bomokandi to Amadi the distance overland is about 55 miles, but the Uelle follows a more circuitous course to the north, bending round in the shape of a great bow. The altitude of the Uelle, which at Bomokandi is $203+$ feet, is found at Amadi to be 2240 feet, and the fall of the river therefore is a little more considerable; moreover, at the rapid of Panga is a waterfall, though of no great size. I have been informed from reliable sources that the waterfall is formed by a diabase-dyke 100 feet wide, striking W.N.W. and E.S.E. I was unable to verify this interesting point, or to gather more details about it, as I had to follow another route.

Nearer Amadi, granite is in eridence, forming sereral rapids in the vicinity. 
The Iron-Mountains of the Uelle.

$$
\text { Amadi-Poko. }
$$

At a distance of about 15 miles from tmadi we came across an important group of hills, the principal being Mount Angba, situated on the right bank of the Celle. North of Mount Angba is Mount Lingwa; southward, but across the Uelle, are seen Mount Mandjana and other minor hills.

The altitude of Mount Angba (by hypsometric observation) is about 2867 feet above sea-level, the summit being nearly 650 feet above the level of the river. The eastern face is, in its upper portion, rather abrupt. On the south and south-west, the slope is also very steep. North-westward, the ground falls away more gradually, and northward extends towards Mount Lingwa in the shape of a long ridge.

The mountain is an enormous mass of iron-ore, stretching for a couple of miles in length in a north-and-south direction, by about half a mile in width. Near the top immense beds of hæmatite are laid bare, in a series of layers resting on edge, and several hundred feet thick. The strike is N. magn. to $20^{\circ} \mathrm{W}$., and the dip $60^{\circ}$ to $70^{\circ}$ westward. The rocks on the top appeared to affect the compass.

This group of hills, comprising Mounts Angba, Lingwa, Mandjana, and others, has somewhat the shape of a range, not well-defined, but extending apparently in a southerly direction towards Poko. Hills of similar nature situated between the Uelle and the Bomokandi lead us to suppose that the range may be continuous as far as Poko, where Mount Madjema, another iron-ore mountain, is also to be seen. The iron-ore met with in this group is mostly a massive black hæmatite, and appears to be very similar to the iron-ore found on Mounts Gaima and Tena (see pp. 648, 651).

Eastward of Mount Angba, a few miles farther on, granite reappears at a rapid on the river, and so it seems probable that the iron-ore beds of Mount Angba are interstratified with the crystalline series, but no direct evidence of this could be gathered. By tho overland route, passing a few miles north of the mountain, on the ridge that extends towards Mount Lingwa, the only rocks observable are layers of hæmatite and large stretches of limonitic puddingstone.

\section{Niangara-Ndoruma.}

Past Suronga, which has an altitude of about 3260 feet, and towards Niangara, the rocks are of metamorphic type. The rapid called $\mathrm{Naka}$ is formed by a band of quartzite, striking north and south, with a slight westerly dip. At a stream called Kitali, not very far west from Niangara, we noticed mica-sch ist also trending north and south. At Niangara the altitude of the Uelle River is 2230 feet.

North of Niangara is a rery flat country, devoid of hills and 
Vol. 6r.] NORTH-EASTERN TERRITORIES OF THE CONGO FREE STATE. 64i

but slightly undulating. To show the slight difference of eleration in that part, the altitudes of the different stations may be quoted, as follows :-Niangara, 2360 feet; Bafuka, 2460; Ndoruma, 2500; Yakuluku camp, 2430; and it may be here mentioned that the three last-named places are almost on the apex of the watershed between the Nile and Congo Basins. This divortium aquarum does not present, however, the aspect of a more or less definite ridge, but rather of a monotonous plain or level plateau, where the many tributaries of both basins intermingle their springs and courses into an inextricable network.

According to the seasons, which here become well defined, the country, in the dry period of the year, is so parched and dry, as to be often waterless over large tracts; while, in the rainy part of the year, it becomes extremely marshy, on account of the predominantlyargillaceous character of its subsoil, and the watercourses, having very little fall, are then expanded into enormous swamps.

Little geological information is to be gleaned from this zone, clay appearing to constitute most of the subsoil, but being frequently overlain in its higher parts by limonitic rocks. Near Bafuka two ridges of the limonitic formation were seen striking north and south.

Towards Tambura, to the north of Ndoruma, the country becomes hilly again, and the watershed is more distinctly defined by large outcrops of gneiss of markedly-foliated structure, apparently dipping south-eastward at a low angle. In these gneisses I hare noted, as accessory minerals, garnets, a little tourmaline, and some pale-green crystals of kyanite; black flakes of mica were also abundant.

\section{The Mount-Bundukwa Group of Hills.}

Travelling eastward from Ndoruma, a little to the south of the border, we reached the knot of hills, situated near long. $29^{\circ} 10^{\prime}$ east and lat. $4^{\circ} 23^{\prime}$ north, comprising Mount Baghinze in the Bahr-elGhazal, and Mounts Bundukwa, Nangango, and Yambili, on the Congo side of the frontier. Between Ndoruma and here, the intervening country presents no hills, only large undulations, forming the shallow valleys of the tributaries of the Uelle.

Clay and limonitic puddingstone were here the only rocks met with, as far as Yakululu. Some 12 miles east of that place, appears the group of the Bundukwa Hills, a possible remnant of what may have been once a mountain-chain, ranging north-west and south-east, and perhaps connected with hills of a similar nature situated in the Nile Territory.

Looking eastward from the top of those hills, one can see that the country resumes its monotonous aspect of a level plain without any noticeable elevations.

Mount Bundukwa ( 3225 feet above sea-lerel) itself is about a mile and a half in length in a north-westerly and south-easterly 
direction, by half a mile in width. Its elevation abore the neighbouring plain is nearly 600 feet. The plains surrounding these hills are thickly clothed in underwoods of brush and scrub, but the greater part of the mountains is bare of all vegetation, as generally are most granitic peaks.

The formation is a strongly-foliated gneiss, the laminæ of which show much contortion and crumpling. Bands of quartz, of black mica, and others of more felspathic nature, alternate successively one with the other in many places. The strike of this formation varies between $30^{\circ}$ and $50^{\circ} \mathrm{W}$. of $\mathrm{N}$., but may be said to arerage a north-westerly and south-easterly direction. At the top of Mount Bundukwa the dip is $80^{\circ}$ to $85^{\circ}$ south-westward, but at the foot of a cliff on the north side, and nearer the level of the plain, we found the beds less steeply inclined, dipping there only $55^{\circ}$ to $60^{\circ}$ south-westward.

The rocks found at Mount Bundukwa offer an element of interest, in having enclosed within them large crystals of kyanite. Occasionally, garnets and tourmaline were also noted in the rocks.

Mount Yambili, situated next to Mount Nangango, and about $2 \frac{1}{2}$ miles east of Mount Bundukwa, is identically of the same nature as the preceding, but on its western side we found at the foot of the hill blocks' of granite formed of large elements, and from those blocks specimens of mica in slabs 4 to 5 inches square were obtained.

The plains surrounding the hills are mostly made up of alluvium, with here and there small rocky ontcrops of a character analogous to those observed on the bigger hills.

\section{Bomokandi River-Mount Tena.}

Going up the Bomokandi River from Poko to Rungu, granitic rocks are seen at two rapids situated between these two localities, but no strike can be noted.

East of Rungu the road follows a swampy tract of land on the northern bank of the river. About 20 miles west of Mount Tena, granite appears before one reaches the mountainous group. Here, Mount Tena forms a prominent feature of the landscape, rising to a height of 4900 feet above sea-level. The mass of the mountain is about 3 miles in length from north-west to south-east, and a mile in width. Its northern extremity is prolonged north-westward by a series of hills, of lesser elevation, towards and up to Mount Negbada. Mount Tena at its crest forms a succession of three rocky summits trending in the axial north-westerly and southeasterly direction, the central summit being slightly the highest. At the foot of Mount Tena iron-bearing rocks only are in evidence, and the whole mountain is a mass of iron-ore. Near the top appears an enormous outcrop of massive $\mathrm{h} \rightsquigarrow \mathrm{matite}$, with magnetite disposed in beds striking north and south, and dipping westward about $80^{\circ}$. On the east side the slope is precipitous, and presents the aspect of a cliff formed by the outcrops of iron-ore. 


\section{The Limonitic Conglomerates.}

In travelling through the Uelle district, the observer cannot fail to be impressed by the enormous development of limonitic rock. As soon as one leares Buta and the Rubi basin, this rock is most frequently seen in isolated blocks or sheets of a dark-brown colour, of medium hardness and density. The constituent elements seem to be rounded lumps of iron-ore with clayey impurities, cemented together by oxide of iron. Frequently, small pieces of rounded quartz were seen embedded in the matrix, as well as sand.

Without in any way exhibiting a stratified appearance, the rock nevertheless offers the aspect of being in many places of the nature of a sedimentary deposit. Its thickness nowhere exceeds 30 feet, and probably averages in most places from 6 to 10 feet only.

Nearly the whole of the country north of the Uelle presents to view no other rock. In the southern part it is constantly seen in patches on the rises of the undulating country.

It is a noticeable fact that the mountainous region of Arebi is, in its hilliest part, comparatively free from limonitic conglomerate, and that this is more abundant on the lower elerations, especially below the Mount-Angba hills and Mount Tena.

At the base of Mount Tena and in the vicinity is an exposure of limonitic conglomerate which deserres special mention. It covers an area which may be described as the more level ground adjoining on the south and west. It is not seen on the north or east side. This conglomerate has the aspect of a surface-formation deposited horizontally, of no great thickness (probably here not exceeding 30 feet). It is composed of large waterworn fragments, irregular in size and shape, but of identical nature with the iron-ore found in beds at the summit of the hill, and cemented together by oxide of iron.

This superficial formation is no doubt the result of the work of denudation and erosion of the iron-ores of the mountain, and its peculiar appearance here has suggested to me the possibility that all the limonitic rocks found so abundantly in the Uelle are the product of denudation and erosion of iron-mountains such as have just been described, or even of other iron-bearing veins, perhaps at present covered up. The work of redeposition took place at a time when the Uelle Basin may have been more or less a succession of shallow lakes and vast swamps. Then the alteration and redistribution of the ferruginous materials would have been attended by every condition favourable to the formation of such limonitic deposits. After being deposited over extensive tracts of country, the limonitic conglomerate has been removed by erosion along some of the watercourses, and this accounts for the formation being invariably found upon the summits of the gentle undulations. The process of formation of these conglomerates is not yet at an end, and in close proximity to the iron-mountains it is still in operation.

In presenting this riew of the possible origin of these limonitic conglomerates, I wish it to be understood that it appears to me 
to be the simplest hypothesis that could suggest itself, from the geological aspect of the country, but that as yet too little information is available, and my observations are too incomplete, to advance more precise conclusions.

No fossils have been found in these limonitic conglomerates, so far as $I$ am aware.

A practical aspect of their occurrence is that they constitute an excellent material, always ready to hand, for the making of hard roads. This should be of importance to the Congo State Government, who are, I believe, now engaged in constructing such roads.

The superficial limonitic formation described is not exclusively confined to the Uelle district, and similar rocks are found in many parts of Africa, on the western coast, and in most districts of the Congo. Referring to the Katanga, and quoting the eminent authority of Dr. E. Dupont in support, the learned geologist Cornet describes it as follows ${ }^{1}$ :-

\footnotetext{
"These deposits are generally of a yellowish-red or brick colour, due to a large proportion of hydrated oxide of iron. It is this lhydrated oxide of iron which, in concreting in the mass of the material, principally near the base, gives rise to beds, lumps, or nodules often embedding rolled pebbles in a sort of impure limonite of cellulous and scoriaceous aspect. The proportion of iron contained is often sufficient to allow of its being used as iron-ore by the natives. Where the superficial action of water has taken off the soft parts of the deposit, the scoriaceous limonite appears in isolated blocks on the surface, or constituting floors often of considerable extent.... This scoriaceous limonite is more especially found where the subsoil is made up of practicallyimpermeable rocks.'
}

Dr. Cornet gives the name of ' red deposit' to this formation in the Congo, and remarks, very justly, that its only point of resemblance to typical laterite lies in the possession of a brick-red colour.

\section{Arebi-Mount Gaima.}

The south-eastern portion of the district, comprised between the Uelle-Kibali and the Bomokandi Rivers, forms a hilly and even mountainous country with Arebi for a centre, averaging in altitude nearly 3000 feet. At the headwaters of the Uelle-Kibali, near Lake Albert and the Nile Territories, the ground is still higher, and there probably exceeds 3600 feet in average altitude. This hilly zone appears to be entirely granitic in nature, and some prominent mountains, such, for instance, as Mrount Tiberi (4210 feet above sea-level), are solid masses of granite. The whole extent of country west of Arebi towards Gumbari, and north towards Mount Combe, is granitic. Nearer Arebi, a little farther north, rocks more basic in appearance are occasionally met with. At the junction of the Motu and Arebi rivers a phyllite was observed, in a small outcrop striking north-worth-west and south-south-east, with an easterly dip.

1 Ann. Soc. géol. de Belg. rol. xxi (1892-94) Mém. pp. 230 \& 231. 
Vol. 6I.] NORTH-EASTERN TERRITORIES OF THE CONGO FREE STATE. 651

Farther north, near Vankerckhovenville, ${ }^{1}$ and on the Uelle-Kibali, Mounts Gaima and Yagu present some points of interest in their great analogy of structure with Mount Tena, iron-ore beds being also much in evidence. (See fig. 1, p. 652.)

Mount Gaima (3960 feet above sea-lerel) is situated about 8 miles west of Vankerckhovenrille, and is quite close to the UelleKibali River. Similarly to Mount Tena, it presents in its upper part great beds of iron-ore striking north-west and south-east, but here the dip is easterly at an angle of $54^{\circ}$. These ferruginous beds appear to be underlain on the west side by a diabasic rock, and are probably interstratified with it. At the base of the hill, near the river, and on the east side, the ground is thickly covered by a bed of pebbles, of the same nature as the iron-ore met with on the top; but no conglomerate is to be seen, and the pebbles are not cemented together.

The iron-ore of Mount Gaima is a $\mathrm{h} æ m$ atite of rery dense character. The beds are magnetic on the summit.

Mount Yagu ( $\$ 400$ feet above sea-lerel) is a few miles farther to the south, and has also a stratum of iron-ore near its summit. The strike bere is east and west, and the dip northerly. The difference of strike and dip from those observed on Mount Gaima points to local displacement of the beds. The thickness of the iron-ore formation here was estimated at 200 or 300 feet; it was observed on the northern face, where the rocks form a precipitous cliff.

The natives of that part procure their iron for making knives, spears, etc. from this mountain, at a spot where the ore is much softer than elsewhere, and brittle. In their primitive attempts at mining they have dotted the hill-slopes round about with many shallow pits, the biggest being hardly wide enough for a man to crawl into.

From Vankerckhorenville to Dungu a kind of phyllite covers a fairly-wide extent of country, being first seen at Dungu, and then at the Rapids of Makassa and in places as far as the River Obu.

In the neighbourhood of Vankerckhovenville itself outcrops of diabase were met with.

\section{Vankerckhovenville-Farach.}

In travelling in a north-easterly direction, towards Farach, a small outcrop of gneiss was met with between the Uelle-Kibali and the Nzoro Rivers, striking north and south, and dipping about $11^{\circ}$ eastward. Farther on, a small hill, situated about 10 miles north-east of Vankerckhovenville, forms an outcrop of diabasic rock. Thence onward to Farach the country becomes almost level, and offers to view only some granitic rocks, specimens of which were obtained at the Rivers Kwado and Aro respectively, and also between the Nzoro and the Uelle-Kibali Rivers.

${ }^{1} V K H$ on the map (Pl. XLII), just across the Nzoro River from Mount Gaima. 


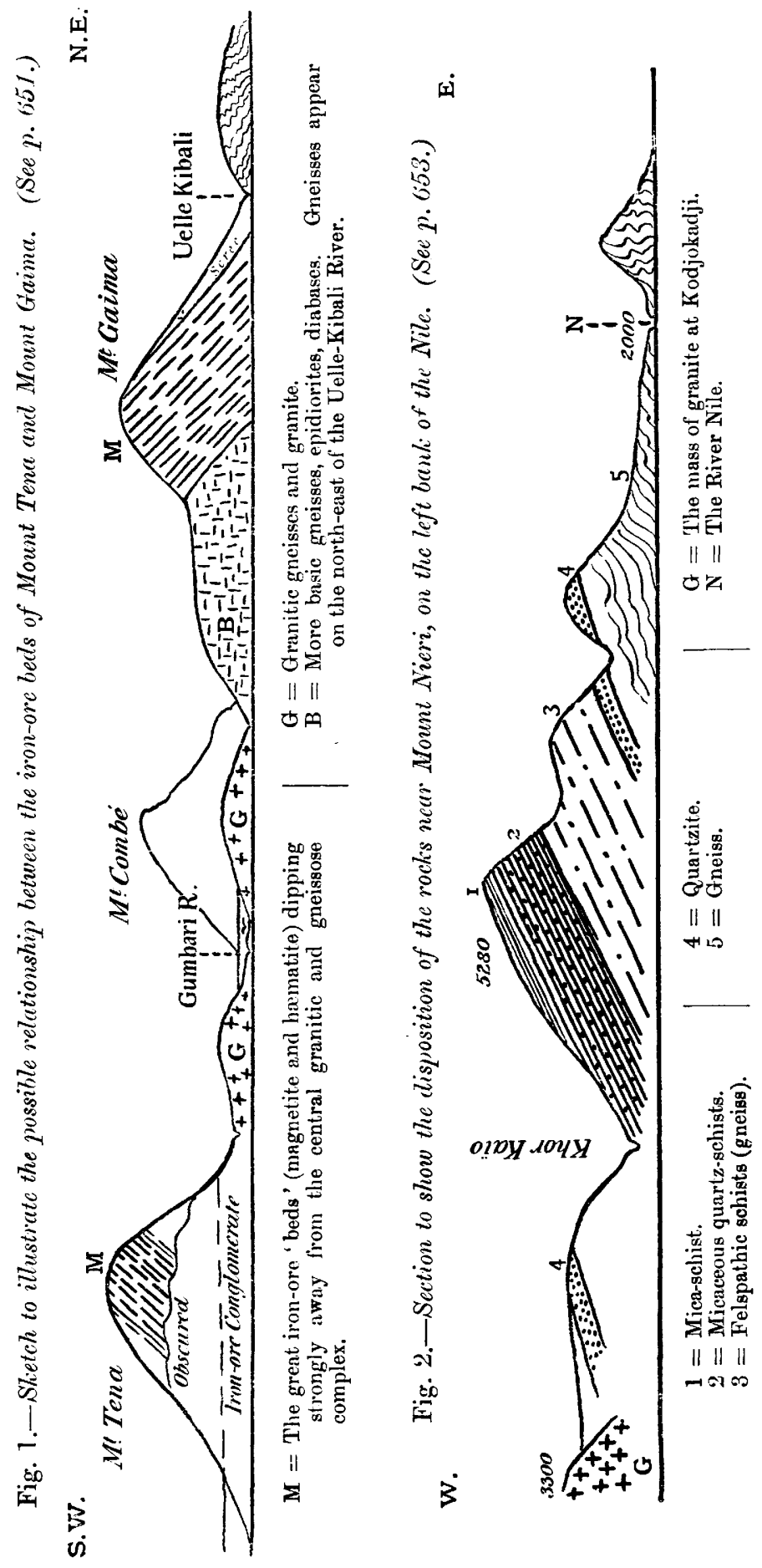


Vol. 6r.] Geologi of Paht of the congo fReE state.

\section{The Nile Territory (Lado Enclave).}

The basin of the Uelle rises gradually up to the watershed dividing it from the Nile Basin. At its highest point, which is situated a little farther east than Aba, I came across granitoid gneiss.

Travelling eastward, up to Loka, patches of gneiss are the only rocks in eridence. At Loka, Mount Gumbali, the highest summit of that neighbourhood, reaches an altitude of 5730 feet above sea-level, being 2450 feet above the surrounding country, and the mountain appears to be wholly built up of $\mathrm{granite.} \mathrm{It} \mathrm{is} \mathrm{a}$ mountain with a double summit, of which the lower dome, under the influence of weathering, has peeled off near the top in such a way that, seen from Loka, the shape bears some resemblance to a Roman helmet.

Going in a southerly direction from Loka, the ground is found to become considerably lower, and, at the crossing of the ralleys of the

Fig. 3.-Section parallel to that shown in fig. ? (p. 652), but W.

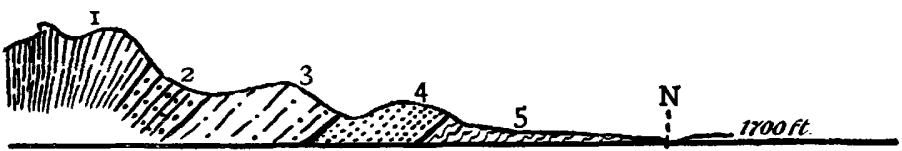

[For explanation, see fig. 2, p. 652.]

Kidju and the Kaia whole series of gneisses and metamorphic rocks are met with, striking nearly due north and south, and undulating with the country.

Towards Kodjokadji the country is again higher and more granitic in character, and forms a small plateau bordering on the Nile. This plateau breaks into the Nile Valley by two successive ridges, ranging north-west and south-east, built of highlscrystalline rocks. The Nile Valley all along these ridges narrows down extremely, and the river is interrupted by innumerable rapids.

In the valley itself, and near the Nile, the predominant rock is gneiss, exposed in nearly-vertical beds. These, as we proceed from east to west, are seen to alter their dip gradually into a more horizontal position, until, approaching the summit of the ridges, we find some quartzites and mica-schists dipping southwestward at an angle of only $25^{\circ}$ to $30^{\circ}$. This formation strikes $40^{\circ} \mathrm{W}$. of $\mathrm{N}$., averaging nearly north-west and south-east, and is both regular and persistent.

The valley of the Nile along this mountainous ridge has an altitude of between 1800 and 2000 feet (above sea-level).

Lower down the Nile, towards Redjaf, several dykes of a species 
of basic andesite appear to cut through the gneiss in a southwesterly and north-easterly direction. At Redjaf, the mount of that name is an isolated hill of $\mathrm{gneiss}$, rising about 300 feet above the level of the Nile.

Returning from Redjaf towards Loka, one crosses the Dinkala Hills, a granitic group of some importance. From these bills to Loka, bands of metamorphic rocks were observed, striking very regularly north-west and south-east.

\section{SUMMARX.}

The Uelle district (leaving aside the small portion described as forming the Rubi Basiu, where the rocks are of more recent formation) consists entirely of an area covered by the very shallow and broad basin of the Uelle River and its tributaries. This long belt is of great geological uniformity, and its whole substratum appears to be granitic and metamorphic.

The granite met at Libokwa, and also that found in the zone of Bima-Bomokandi-Zobia, seems to be of normal type; but, in the absence of specimens, it is difficult for me to attempt to class it definitely. As, however, at the station of Libokwa we noted an isolated block of true gneiss, this would point to the rocks of the whole district having undergone dynamometamorphism.

Towards Mount Angba the country becomes distinctly and entirely metamorphic in character. North of Ndoruma, as well as at Mount Bundukwa, the rocks also are all metamorphic, a fact which leads one to infer that the entire country lying north of the Uelle, although offering to view only allurium and limonitic rocks, is close to its surface underlain by metamorphic rocks of the same nature.

Recent eruptive rocks, so far as I have been able to ascertain, are apparently very rare.

In the south-eastern mountainous portion of the Uelle district, rocks of a more basic composition are as a rule prevalent, and may be said to.form an intrusive mass, on the margin of which abut the iron-ore beds of Mounts Tena and Gaima. These beds were probably upthrust by the underlying diabasic rock, as seen on Mount Gaima.

The close resemblance of the iron-ore of Mount Tena with that of Mount Gaima suggests the possibility that both may have belonged at one time to the same formation, subsequently disrupted by the intrusive mass.

Throughout the Uelle district the abundant argillaceous deposits represent the ancient alluvial formations, and to some extent also the decomposition in situ of the granitic rocks so prevalent everywhere in the district. The frequent occurrence of the limonitic rocks probably also bears some relation to the numerous iron-ore hills existing in the district, as already pointed out. Both these formations are evidently of comparatively-recent date. 
Quart. Journ. Geol. Soc. Vol. LXI, Pl. XLII.

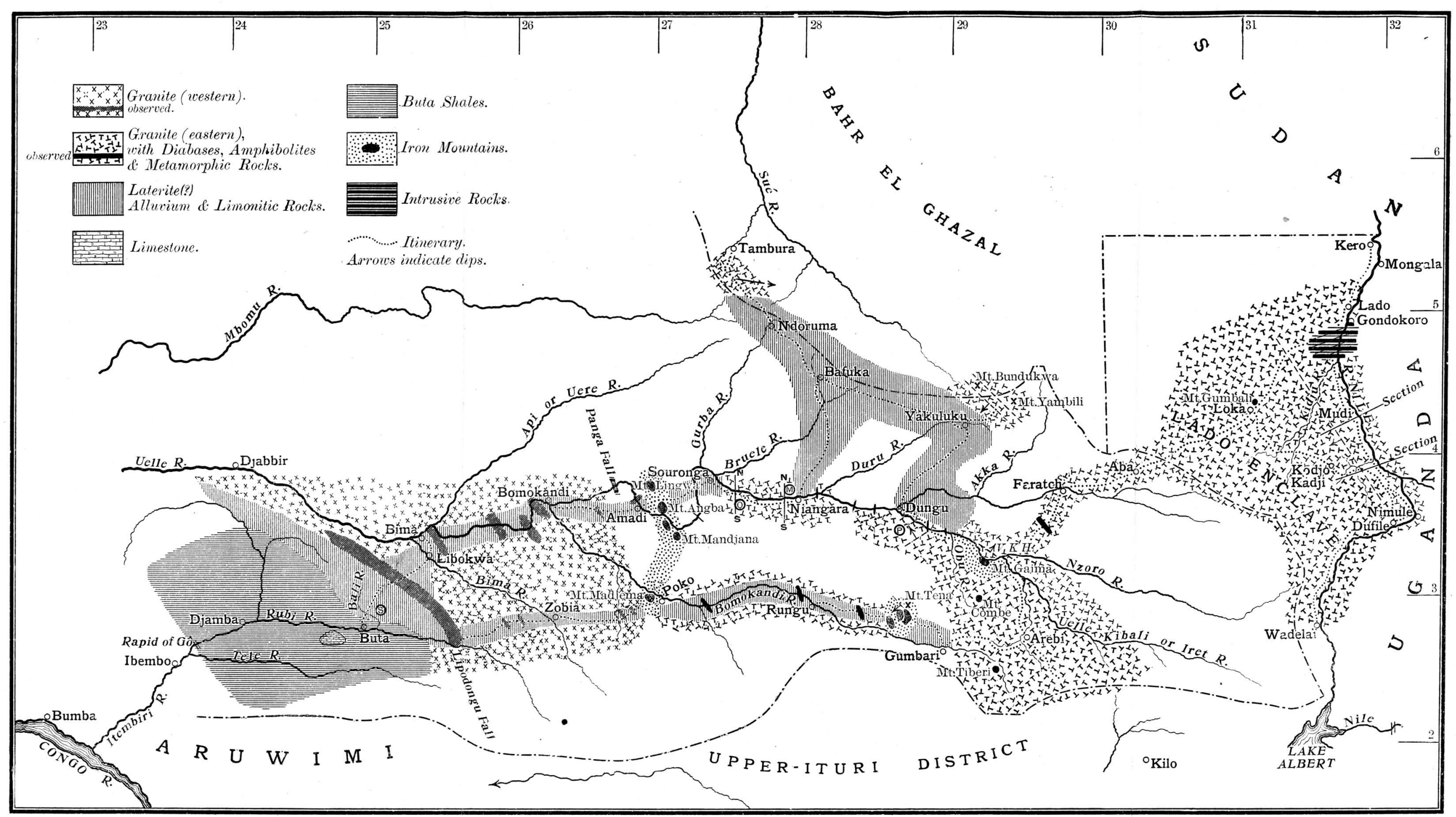

Grological Sketch-map of the North-Eastern Territories of the Congo Free State and the Lado Enclave. 
Vol. 61.] PETROLOGY OF ROCKS FROM THE CONGO FREE STATE.

In the Nile Territory the rocks are all more or less metamorphic, but the country shows here and there peaks of granite (such as Mount Loka, the Dinkala Hills, and Kodjokadji) piercing through the stratified series of gneiss, quartzites, and mica-schists.

Recent eruptive rocks are comparatively rare, such being found only at Redjaf. These are dykes of basic andesitic rock, which intersect the gneissose series.

Similarly to the greater part of Equatorial Africa, this area appears to be deroid of fossils, although it is possible that further and more competent search may yet reveal some.

It will be seen that the foregoing observations tend to confirm the views already held as to the geological features of this portion of the Congo Basin; the granitic and metamorphic primary rocks are present across the whole country from east to west and from north to south, uncovered by any other rocks except the alluvial clays and sands and the nearly-related ferruginous rocks; the grey and red sandstones, so prominent in the regions lying west, south, and east of the Uelle Basin, are conspicuously absent.

\section{Petrological Notes. By J. Alien Howe, B.Se., F.G.S.}

\section{Rocks from the Neighbourhood of Buta.}

Specimen No. $48 .^{2}$-This is a fine-grained, chocolate-coloured, laminated mudstone containing minute flakes of mica. There is no trace of any fossil, unless one or two microscopic pellets may be taken to represent coprolites.

No. 42, Rubi Rirer.-From large blocks apparently emivedded in the clayey alluvium of the river.

It is a compact cream-coloured rock, with well-marked oolitic structure. In the thin slice, opaque, dull, spherical grains are seen in a fairly-large amount of granular crystalline calcite, which forms the matrix. T'he grains are fairly uniform in size, and all possess a well-defined concentric structure; there is no trace of any radial structure, and the material is too dusty in character to give a cross in polarized light. The centres of the grains are usually filled with more or less clear granular calcite, and no organic or clastic bodies have been noticed in them. There are several compound grains, one large grain enclosing one or two smaller ones. (See Pl. XLIV, fig. 2.)

The rock is suggestive of an oolite formed from a calcareous spring, but there is nothing to show that organisms have taken any part in its formation. In places the rock includes small pellets of grey clay [52], and where this is present the limestone tends to assume a stylolitic structure.

${ }^{1}$ These numerals refer to the microscope-slides and rocks deposited in the Museum of Practical Geology, Jermyn Street, London. 
Downloaded from http://jgslegacy.lyellcollection.org/ at University of Liverpool on July 1,2016

Quart. Journ. Geol. Soc. Vol. LXi, Pl. XliII.

FIG. $1 \times 15$ DIAM.

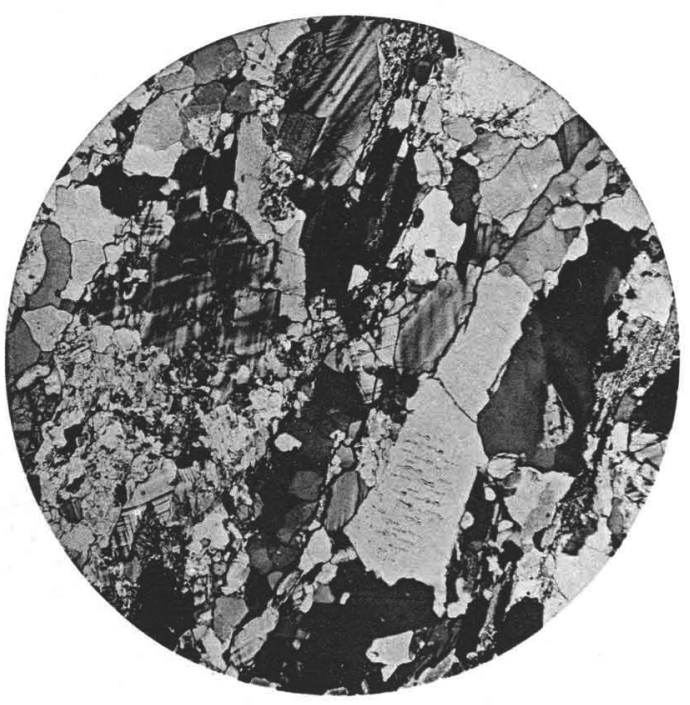

FIG. $2 \times 15$ DIAM.

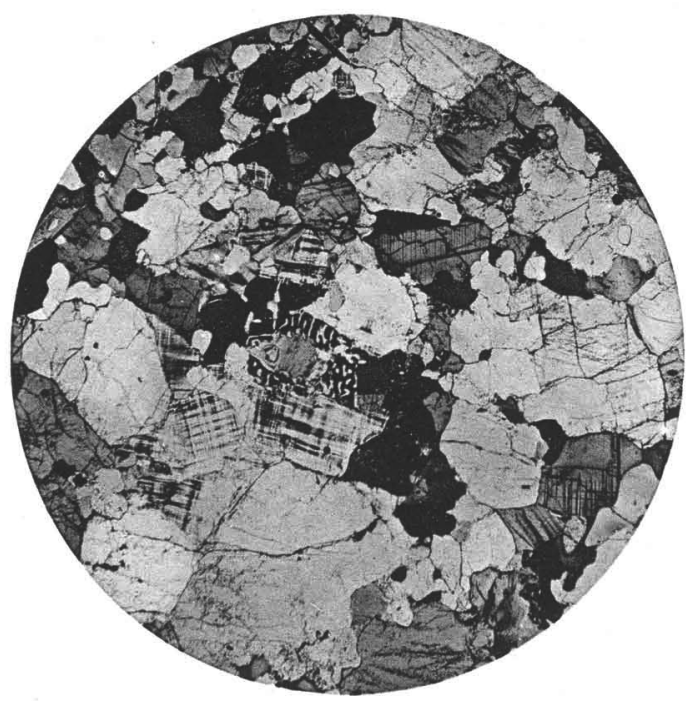

GNEISSES FROM THE CONGO FREE STATE. 
Downloaded from http://jgslegacy.lyellcollection.org/ at University of Liverpool on July 1, 2016

Quart. Journ. Geol. Soc. Vol, LXI, Pl. Xliv.

FIG. $1 \times 15$ DIAM.

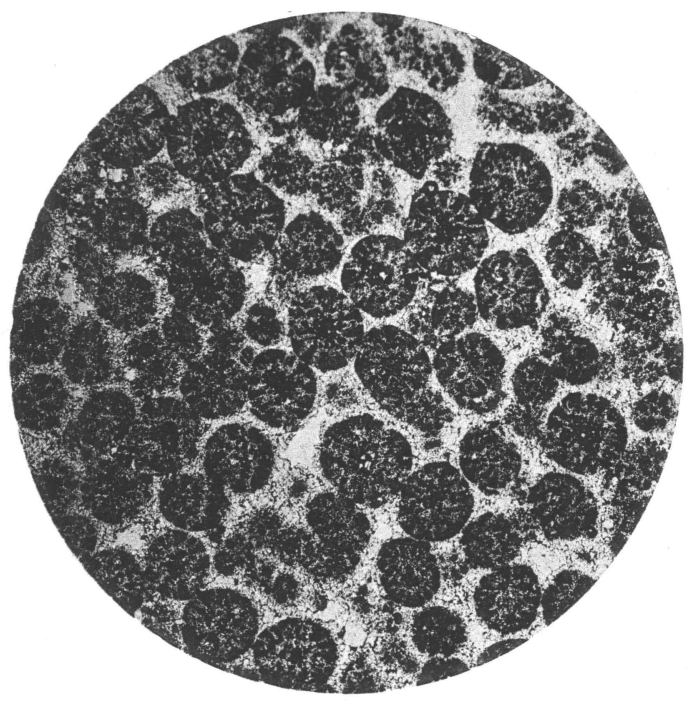

FIG. $2 \times 10$ DIAM.

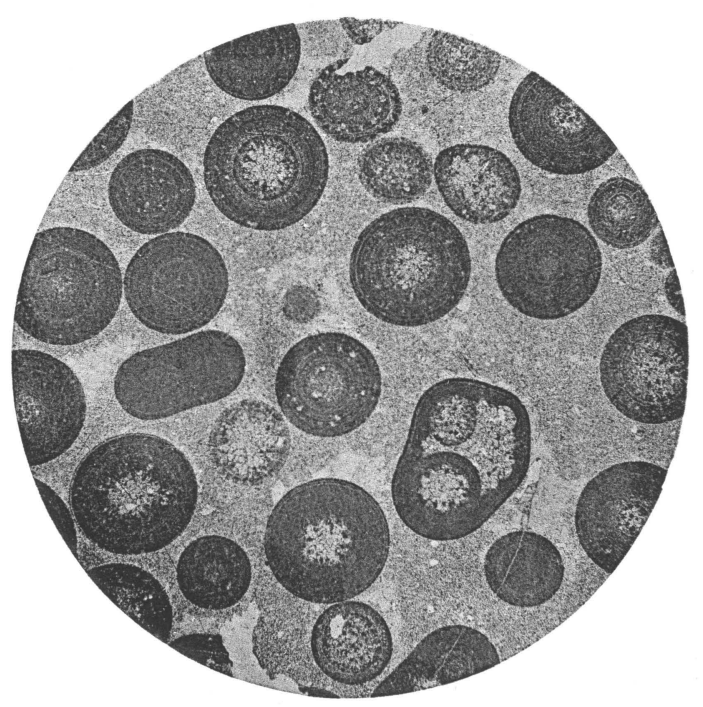

OOLITIC LIMESTONES FROM THE CONGO FREE STATE. 